\title{
IMPLEMENTASI FULL DAY SCHOOL DALAM MENINGKATKAN PRESTASI BELAJAR SISWA KELAS VIII DI MTs. AL-HUSNA KOTA TANGERANG BANTEN
}

\author{
Yayan \\ y2nhariyanti@gmail.com \\ Kantor Kementrian Agama Kota Tangerang Provinsi Banten
}

\begin{abstract}
The purpose of this study was to find out how the implementation of Full Day School in Improving the Learning Achievement of Class VIII Students in MTs. Al-Husna, Tangerang City, Banten. The method used in this research is descriptive qualitative research method, namely by observing the research location, conducting interviews and collecting data from various sources related to the research. The results of this study conclude: The implementation of full day school at MTs Al-Husna has been going well. Students get better report cards. Students are accustomed to praying dhuha, praying dhuhur, asr in congregation, dhikr, and reading the Qur'an, without being ordered by their parents. Students are able to read the Qur'an in accordance with tajwid. Students are able to memorize the Qur'an juz 29 and juz 30.
\end{abstract}

Keywords: Implementation, Full Day School, Learning Achievement.

\begin{abstract}
ABSTRAK
Tujuan Penelitian ini adalah untuk mengetahui bagaimana Implementasi Full Day School Dalam Meningkatkan Prestasi Belajar Siswa Kelas VIII Di MTs. Al-Husna Kota Tangerang Banten. Metode yang digunakan Penelitian ini adalah metode penelitian kualitatif deskriktif, yaitu dengan melakukan observasi ke lokasi penelitian, melakukan wawancara dan mengumpulkan data dari berbagai sumber yang berhubungan dengan penelitian. Hasil penelitian ini menyimpulkan: Implementasi full day school di MTs Al-Husna sudah berjalan dengan baik. Siswa mendapatkan nilai raport lebih baik. Siswa terbiasa shalat dhuha, shalat dhuhur, ashar berjama'ah, dzikir, dan membaca al-Qur'an, tanpa diperintah oleh orang tua. Siswa mampu membaca al-Qur'an sesuai dengan tajwid. Siswa mampu menghafal Al-Qur'an juz 29 dan juz 30.
\end{abstract}

Kata Kunci: Implementasi, Full Day School, Prestasi Belajar.

\section{Pendahuluan}

Pendidikan merupakan suatu kebutuhan bagi kehidupan umat manusia. Karena dengan pendidikan akan membantu membentuk kepribadian siswa di masa yang akan datang dan juga mempunyai fungsi untuk mengembangkan kemampuan serta meningkatkan kualitas kehidupan manusia Indonesia.Setiap manusia memiliki potensi yang berbeda. Potensi perlu untuk dikembangkan agar bermanfaat dikemudian hari. Sarana yang paling strategis untuk mengembangkan potensi adalah melalui pendidikan. Pendidikan merupakan usaha sadar, terencana dan diupayakan untuk memungkinkan siswa secara aktif mengembangkan potensi diri, baik fisik maupun nonfisik, yakni mengembangkan potensi pikir, sosial, emosional, nilai moral, spiritual, ekonomikal, sehingga ia dapat 
menjalankan kehidupannya sesuai dengan harapan dirinya, keluarganya, bangsa dan negara. ${ }^{1}$

Pendidikan adalah usaha sadar yang ditujukan kepada siswa agar menjadi manusia yang berkepribadian kuat dan utuh serta bermoral tinggi. ${ }^{2}$ Makna pendidikan secara sederhana dapat diartikan sebagai usaha manusia untuk membina kepribadian sesuai dengan nilainilai dan norma-norma yang ada di dalam masyarakat. Pendidikan adalah suatu bimbingan secara sadar oleh pendidik terhadap perkembangan jasmani dan rohani anak didiknya menuju kepribadian yang lebih baik. Pendidikan merupakan proses pengubahan sikap dan tata laku seseorang atau kelompok orang, guna mendewasakan manusia melalui upaya pengajaran dan pelatihan. Dalam pengertian luas, pendidikan juga dapat diartikan sebagai sebuah proses dengan metode-metode tertentu sehingga orang memperoleh pengetahuan, pemahaman, nilai-budaya, sebagai panduan bertingkah laku dan bermasyarakat. ${ }^{3}$ Pendidikan sebagai suatu proses yang secara rasional, sistematik, dan berencana dilakukan untuk mengubah perilaku manusia menuju tahap kematangan yang dikehandaki. ${ }^{4}$

Dari uraian diatas, menunjukkan bahwa pendidikan merupakan sarana yang penting untuk meningkatkan kualitas manusia pada setiap aspek kehidupannya. Melihat begitu pentingnya pendidikan, maka perlu adanya perhatian yang serius

${ }^{1}$ Didi Supriadie dan Deni Darmawan, Komunikasi Pembelajaran, (Bandung: PT Remaja Rosdakarya, 2012), h. 1.

${ }^{2}$ Umar Tirtarahardja dan S. L. La Sulo, Pengantar Pendidikan, (PT Rineka Cipta, 2005), h. 305.

${ }^{3}$ Muhibbin Syah, Psikologi Pendidikan dengan Pendekatan Baru, (Bandung: PT Remaja Rosdakarya, 2006), h.10.

4 Didi Supriadie dan Deni Darmawan, Komunikasi Pembelajaran, h. 2. berkenaan dengan konsep pendidikan agar dapat mencapai tujuan pendidikan secara maksimal. Tujuan pendidikan nasional Indonesia adalah untuk mengembangkan potensi siswa agar menjadi manusia yang beriman dan bertaqwa pada Tuhan Yang Maha Esa, berakhlak mulia, sehat, berilmu, cakap, kreatif, mandiri, dan menjadi warga negara yang demokratis serta bertanggung jawab. ${ }^{5}$

Dengan menjalani proses pendidikan diharapkan siswa dapat aktif mengembangkan potensi dirinya untuk memiliki kekuatan iman, kedalaman, dan keterampilan ilmu sehingga dapat bertanggung jawab dalam mengemban tugas hidupnya. Pendidikan nasional adalah pendidikan yang berdasarkan pancasila dan Undang-Undang Dasar Negara Republik Indonesia Tahun 1945, yang berakar pada nilai-nilai agama, kebudayaan nasional Indonesia serta tanggap terhadap tuntutan perubahan zaman.Pendidikan dapat menjadi tolak ukur bagi kemajuan dan kualitas kehidupan suatu bangsa, sehingga dapat dikatakan bahwa kemajuan suatu bangsa dapat dicapai salah satunya adalah dengan melalui pembaharuan serta penataan pendidikan dengan baik. Jadi keberadaan pendidikan memiliki peran yang sangat penting terutama dalam menciptakan kehidupan masyarakat yang cerdas, pandai, berilmu pengetahuan, berjiwa sosial, demokratis, serta berakhlak mulia. Setiap anak perlu untuk mendapatkan ilmu agama dan ilmu pengetahuan umum secara proporsional. Sebagai bekal mereka untuk mengatasi setiap tantangan yang akan mereka temui sepanjang hidupnya. Kenyataannya kebanyakan para orang tua

${ }^{5}$ Undang-undang Republik Indonesia No 20 tahun 2003 tentang Sisdiknas dan Peraturan Pemerintah Tahun 2010 tentang Penyelenggaraan Pendidikan serta Wajib Belajar, (Bandung: Citra Umbara, 2011), h. 6. 
melimpahkan tanggung jawab mendidik anak sepenuhnya kepada lembaga pendidikan. Meski sebenarnya pendidikan anak adalah tanggung jawab bersama keluarga, sekolah dan masyarakat. Para orang dewasa berkewajiban mendampingi proses belajar anak-anak. Sering kali tugas pendampingan masa belajar anak ini hanya terjadi saat anak di sekolahan. Sedangkan saat dirumah atau di masyarakat, anak tidak memperoleh pendampingan belajar yang baik.Perubahan sosial budaya yang terjadi di masyarakat, dari masyarakat agraris menuju ke masyarakat industri. Perubahan tersebut jelas berpengaruh pada pola pikir dan cara pandang masyarakat. Kemajuan sains dan teknologi yang begitu cepat perkembangannya, terutama teknologi komunikasi dan informasi lingkungan kehidupan perkotaan yang menjurus kearah individualisme.

Perubahan sosial budaya memengaruhi pola pikir dan cara pandang masyarakat. Salah satu ciri masyarakat industri adalah mengukur keberhasilan dengan materi. Hal ini sangat berpengaruh terhadap pola kehidupan masyarakat yang akhirnya berdampak pada perubahan peran. Peran ibu yang dahulu hanya sebagai ibu rumah tangga, dengan tugas utamanya mendidik anak, mulai bergeser. Peran ibu di zaman sekarang tidak hanya sebatas sebagai ibu rumah tangga, namun seorang ibu juga dituntut untuk dapat berkarier di luar rumah. Sehingga jumlah orang tua yang bekerja meningkat, pengawasan orang tua kepada anaknya berkurang, terutama yang berhubungan dengan aktivitas anak setelah pulang dari sekolah. Kemajuan ilmu pengetahuan dan teknologi begitu cepat sehingga jika tidak dicermati, maka kita akan menjadi korban, terutama korban teknologi komunikasi. Dengan semakin canggihnya perkembangan di dunia komunikasi, dunia seolah-olah sudah tanpa batas dengan banyaknya program televisi membuat anak-anak lebih enjoy untuk duduk di depan televisi dan bermain play station (PS). Adanya perubahan-perubahan di atas merupakan suatu sinyal penting untuk dicarikan alternatif pemecahannya. Dari kondisi seperti itu, akhirnya para praktisi pendidikan berpikir keras untuk merumuskan suatu paradigma baru dalam dunia pendidikan. Sebagai jawaban atas permasalahan ini beberapa sekolah mendesain kurikulumnya dengan sistem full day school. Yakni sebuah sekolah yang memiliki jam belajar lebih lama dibandingkan dengan sekolah-sekolah pada umumnya. Sekolah dengan sistem full day school memadukan sistem pengajaran yang intensif yakni dengan menambah jam pelajaran untuk pendalaman materi pelajaran serta pengembangan diri dan kreatifitas. Pelaksanaan pembelajaran yang dilaksanakan di sekolah mulai pagi hingga sore hari, secara rutin sesuai dengan program pada tiap jenjang pendidikannya. Dalam full day school, lembaga bebas mengatur jadwal mata pelajaran sendiri dengan tetap mengacu pada standar nasional alokasi waktu sebagai standar minimal dan sesuai bobot mata pelajaran, ditambah dengan model-model pendalamannya. Jadi yang terpenting dalam full day school adalah pengaturan jadwal mata pelajaran.

Full day school menarik banyak orang tua yang mempunyai mobilitas tinggi atau orang tua yang menyadari tantangan zaman yang semakin berat dimana peran orang tua sudah tidak dominan lagi dalam pendidikan anak. ${ }^{6}$ MTs Al Husna adalah salah satu lembaga pendidikan dengan sistem full day school. Lembaga ini mencoba memadukan antara pengetahuan umum dan pengetahuan agama dalam kurikulumnya. MTs Al

\footnotetext{
${ }^{6}$ Jamal Ma'mur Asmani, Full Day School Konsep Manajemen dan Quality Control, (Yogyakarta: Ar-Ruzz Media, 2017), h. 31.
} 
Husna ini hadir dengan tujuan agar sekali menempuh dalam lembaga pendidikan formal, siswa dapat memperoleh pendidikan umum dan sekaligus pendidikan agamanya. MTs Al Husna adalah sekolah yang didesain sedemikian rupa dengan harapan menghasilkan alumni yang berkualitas bukan hanya dari sisi pendidikan umumnya saja, tetapi juga pendidikan agamanya. Atas dasar beberapa pernyataan di atas, penulis tertarik untuk meneliti penerapan sistem full day school di lembaga pendidikan tersebut.

\section{Kajian Teori \\ 1. Pengertian Full Day School}

Secara etimologi kata full day school berasal dari bahasa inggris. Full mengandung arti penuh, dan day artinya hari. Sedangkan school mempunyai arti sekolah. Jika digabung, akan mengandung arti sekolah sehari penuh. Sedangkan menurut terminologi, ada beberapa pendapat yang menjelaskan tentang pengertian full day school yaitu: Full day school adalah sekolah sepanjang hari atau proses belajar mengajar yang diberlakukan dari pagi sampai sore hari, mulai pukul $07.00-15.30 \mathrm{WIB}$, dengan durasi istirahat setiap dua jam sekali. Dengan demikian, sekolah dapat mengatur jadwal pelajaran dengan leluasa, disesuaikan dengan bobot mata pelajaran dan ditambah dengan pendalaman materi. ${ }^{7}$

Jamal Ma'mur Asmani menyatakan bahwa full day school merupakan model sekolah umum yang memadukan sistem pengajaran Islam secara intensif, yaitu dengan memberi tambahan waktu khusus untuk pendalaman keagamaan siswa. Biasanya jam tambahan tersebut dialokasikan pada jam setelah shalat dzuhur sampai shalat ashar sehingga

\footnotetext{
${ }^{7}$ Baharuddin, Pendidikan dan Psikologi Perkembangan, (Jogjakarta: Ar-Ruzz Media, 2010), h. 221.
}

praktis sekolah model ini masuk pukul 07.00 WIB pulang pada pukul 15.15 WIB. Sementara pada sekolah-sekolah umum, anak biasanya sekolah sampai pukul 13.00 WIB. ${ }^{8} \quad$ Sedangkan Sulistyaningsih menyatakan bahwa "sekolah bertipe full day ini berlangsung hampir sehari penuh lamanya, yakni dari pukul 08.00 pagi hingga 15.00 sore". Dengan demikian, sistem full day school adalah komponenkomponen yang disusun dengan teratur dan baik untuk menunjang proses pendewasaan manusia (siswa) melalui upaya pengajaran dan pelatihan dengan waktu di sekolah yang lebih panjang atau lama dibandingkan dengan sekolah-sekolah pada umumnya. ${ }^{9}$

Dari pernyataan-pernyataan tentang full day school di atas dapat ditarik kesimpulan bahwa pengertian full day school adalah sekolah yang pelaksanaannya selama sehari penuh dengan proses pembelajarannya mulai pagi hingga sore yang mana sekolah tersebut memberikan waktu tambahan untuk memperdalam materi pelajaran tertentu.

2. Tujuan Program Full Day School

Tujuan pendidikan merupakan hasil akhir yang diharapkan oleh suatu tindakan mendidik. Mendidik merupakan tindakan sengaja untuk mencapai tujuan. Di dalam suatu organisasi pendidikan, tujuan pendidikan telah terumuskan dalam berbagai tingkat tujuan:

1) Tujuan umum pendidikan nasional Indonesia ialah manusia Pancasila.

2) Tujuan institusional yaitu tujuan yang menjadi tugas dari lembaga pendidikan tertentu untuk mencapainya. Misalnya tujuan pendidikan tingkat menengah berbeda dengan tujuan pendidikan tingkat atas.

8 Jamal Ma'mur Asmani, Full Day School Konsep Manajemen dan Quality Control, h. 19.

\footnotetext{
${ }^{9}$ Wiwik Sulistyaningsih, Full Day School dan Optimalisasi Perkembangan Anak, (Yogyakarta: Paradigma Indonesia, 2008), h. 5.
} 
3) Tujuan kurikuler, yaitu tujuan bidang studi atau tujuan mata pelajaran. Misalnya tujuan IPA, Matematika, atau Bahasa Inggris. Setiap lembaga pendidikan untuk mencapai tujuan institusionalnya menggunakan kurikulum. Kurikulum mempunyai tujuan yang disebut tujuan kurikuler.

4) Tujuan instruksional. Materi kurikulum yang berupa bidang studi terdiri dari pokok-pokok bahasan dan sub pokok bahasan. tujuan pokok bahasan dan sub pokok bahasan disebut tujuan instruksional, yaitu penguasaan materi pokok bahasan/sub pokok bahasan. ${ }^{10}$

Pelaksanaan full day school merupakan salah satu alternatif untuk mengatasi berbagai masalah pendidikan, baik dalam prestasi maupun dalam hal moral atau akhlak. Dengan mengikuti full day school, orang tua dapat mencegah dan menetralisir kemungkinan dari kegiatan-kegiatan anak yang menjerumus pada kegiatan yang negatif. Dalam menerapkan sistem full day school, sekolah memiliki waktu yang lebih panjang dibandingkan dengan sekolah dasar konvensional pada umumnya. Waktu untuk mendidik siswa dalam sistem full day school lebih banyak sehingga tidak hanya teori, tetapi juga praktek. Oleh karena itu, agar semua terakomodir, maka kurikulum program full day school didesain untuk menjangkau masingmasing bagian dari perkembangan siswa. Jadi yang dimaksud dengan tujuan program full day school disini adalah melahirkan manusia yang mampu melakukan hal-hal baru, tidak sekedar mengulang apa yang dilakukan generasi sebelumnya sehingga bisa

${ }^{10}$ Umar Tirtarahardja dan S. L. La Sulo, Pengantar Pendidikan, h. 40. menjadi manusia kreatif, penemu dan penjelajah. $^{11}$

3. Strategi Pembelajaran Sistem Full Day School

Strategi pembelajaran merupakan rangkaian kegiatan, penggunaan metode dan pemanfaatan berbagai sumber daya atau kekuatan dalam pembelajaran. Strategi disusun untuk mencapai tujuan tertentu. Arah dari sem ua keputusan penyusunan strategi adalah pencapaian tujuan. Strategi pembelajaran adalah suatu kegiatan pembelajaran yang harus dikerjakan guru dan siswa agar tujuan pembelajaran yang telah ditentukan dapat tercapai secara efektif dan efisien. ${ }^{12}$

Penggunaan strategi dalam pembelajaran sistem full day school sangat perlu digunakan, karena untuk mempermudah proses pembelajaran sehingga dapat mencapai hasil yang optimal. Tanpa strategi yang jelas, proses pembelajaran tidak akan terarah sehingga tujuan pembelajaran yang telah ditetapkan sulit tercapai secara optimal. Agar pembelajaran dapat berlangsung secara efektif dan efisien maka lembaga pendidikan harus dapat menentukan strategi pembelajaran yang tepat. Strategi dapat dijadikan pedoman dan acuan bertindak yang sistematis dalam pelaksanaan pembelajaran. Bagi siswa, penggunaan strategi pembelajaran dapat mempermudah proses belajar (mempermudah dan mempercepat memahami isi pembelajaran). Karena setiap strategi pembelajaran dirancang untuk mempermudah proses belajar mengajar bagi siswa dan bagi guru.

Strategi pembelajaran full day school sebagian besar waktunya digunakan

\footnotetext{
${ }^{11}$ Suyyinah, Full Day Education: Konsep dan Implementasi, (Malang: Literasi Nusantara, 2019), h. 17.

${ }^{12}$ Wina Sanjaya, Strategi Pembelajaran Berorientasi Standar Proses Pendidikan, (Jakarta: Kencana Prenada Media, 2011), h. 126.
} 
untuk belajar dengan strategi yang menyenangkan bagi siswa, yang bertujuan untuk menggali potensi siswa secara total, dan menitik beratkan pada situasi dan kondisi dimana siswa dapat mengikuti proses belajar dan juga bermain agar siswa tidak merasa terbebani dan bosan berada di sekolah. Karena full day school memiliki banyak strategi dan metode pembelajaran yang bervariasi dan lain dari pada sekolah dengan program reguler. ${ }^{13}$ Strategi harus direncanakan dan dipersiapkan dengan matang dan direalisasikan senyatanya pada saat pembelajaran di kelas. Penggunaan metode yang bervariasi dalam pembelajaran sistem full day school adalah salah satu strategi guru yang dilakukan agar siswa tidak merasa bosan dan jenuh dalam melaksanakan pembelajaran, sehingga motivasi siswa dalam belajarpun dapat meningkat. Strategi harus direncanakan dan dipersiapkan dengan matang dan direalisasikan senyatanya pada saat pembelajaran di kelas.

4. Keunggulan dan Kelemahan Full Day School

a. Keunggulan Full Day School

1. Optimalisasi Pemanfaatan Waktu. Waktu adalah jangka, rentang dan masa. Masa hidup adalah jumlah waktu yang digunakan dalam hidup. Betapa pentingnya waktu, masing-masing orang atau daerah memiliki peribahasa sendiri-sendiri. Orang barat mengatakan, time is money. Sedangkan orang arab mengatakan waktu adalah pedang. Pedang yang ketika salah penggunaannya akan melukai bahkan membunuh diri sendiri.Belajar sepanjang hari adalah bukti penghargaan yang tinggi terhadap waktu. Itulah keunggulan pertama dari sistem full day school. Memanfaatkan waktu secara efektif dan produktif

\footnotetext{
${ }^{13}$ Umar Tirtarahardja dan S. L. La Sulo, Pengantar Pendidikan, h. 23.
}

adalah ciri-ciri orang sukses. Memanfaatkan waktu berarti menggunakan waktu untuk hal-hal yang bermanfaat dan tidak membiarkannya tanpa makna. Orang yang menyadari pentingnya arti waktu pasti akan membuat perencanaan kegiatan secara matang dan terukur, ada target kualitas dan waktu perencanaan yang dicanangkan. ${ }^{14}$ Full day school mendidik anak secara langsung bagaimana mengisi waktu dengan hal-hal yang bermanfaat untuk masa depan. Ada waktu belajar, istirahat, olahraga, bergaul dengan teman, refreshing, latihan pengembangan bakat, berorganisasi dan lain-lain yang positif dan visioner.

2. Menggali dan Mengembangkan bakat. Dengan alokasi waktu yang sangat luas, waktu untuk menggali dan mengembangkan bakat anak terbuka luas. Kegiatan sore hari bisa dimaksimalkan untuk melihat keahlian dan kecakapan anak dalam semua bidang. Dengan memaksimalkan waktu latihan, diharapkan bakat anak cepat terdeteksi. Dari sanalah bakat dipupuk dan dikembangkan secara maksimal. ${ }^{15}$ Sarana prasarana perlu dilengkapi sehingga siswa lebih giat dalam berlatih.

3. Menanamkan Pentingnya Proses. Full day school yang memakan waktu panjang dari pagi hari hingga sore hari mengajarkan kepada anak bahwa keungulan, prestasi dan kehebatan harus dilalui dengan kerja keras, waktu lama, proses yang melelahkan dan konsistensi pada jalan yang benar. Anak akan melihat bahwa dengan waktu belajar yang lebih lama dan

\footnotetext{
${ }^{14}$ Jamal Ma'mur Asmani, Full Day School Konsep Manajemen dan Quality Control, h. 31.

${ }^{15}$ Ibid., h. 37.
} 
lebih keras, dirinya akan semakin terasah kemampuannya, matang kepribadiannya, teruji mentalnya. ${ }^{16}$ Full day school memberi inspirasi besar dalam memompa semangat belajar keras dan menanamkan kegigihan dalam proses sepanjang masa.

4. Fokus dalam Belajar. Waktu belajar yang lebih lama dari sistem sekolah biasa, menjadi kesempatan bagi sekolah untuk membuat jadwal pelajaran secara leluasa, mana yang diajarkan pada waktu pagi, dan mana yang diajarkan pada waktu siang. Full day school mampu memanfaatkan kelebihan waktu yang tidak ada pada sistem konvensional untuk membuat alokasi waktu secara efektif agar fokus dan konsentrasi anak tidak terpecah belah. ${ }^{17}$

5. Kegiatan Anak Terkontrol. Dengan pemberlakuan sistem ini maka anak akan lebih lama berada dalam lingkungan sekolahnya atau selalu berada dalam pengawasan gurunya ketika melakukan kegiatan, sehingga kegiatannya lebih dapat di kontrol dari pada dia berada di luar sekolah. Para guru dapat mengawasi, mengarahkan dan membimbing pergaulan dan kegiatan anak.

6. Pembiasaan Anak dalam Beribadah. Sebagai negara yang beragama tentunya banyak kegiatan yang dilakukan setiap harinya sebagai sarana memperkuat kemampuan spritualnya, khususnya bagi siswa yang beragama islam dapat melaksanakan sholat zuhur dan sholat ashar secara berjamaah, bahkan ditambah tadarus dan kegiatan keagamaan lainnya.

7. Penanaman Akhlak. Kemerosotan moral atau akhlak yang terjadi
${ }^{16}$ Ibid., h. 38.

${ }^{17}$ Ibid., h. 40. sekarang ini akan bisa dikurangi dengan pembelajaran dan pembiasaan akhlak yang baik di sekolah. Tetapi biasanya terhalang oleh permasalahan waktu yang singkat di sekolah, sehingga sistem ini dirasa tepat untuk mengatasinya.

8. Cinta Lingkungan. Penerapan cinta lingkungan akan lebih maksimal dengan mengajak anak untuk samasama merawat dan memelihara lingkungan sekolahnya dengan beberapa kegiatan yang berguna untuk kelestarian lingkungan. Seperti kegiatan kerja bakti.

b. Kelemahan Full Day School

1. Tingkat Stres Yang Tinggi. Anak akan merasa tertekan dan stres karena terlalu lama di sekolah, ini akan terjadi apabila sekolah kurang bisa memberikan porsi waktu yang tepat, kapan istirahat dan kapan berkegiatan.

2. Waktu Untuk Pulang Sekolah. Pada sebagian daerah jarak tempuh anak dari rumah ke sekolah menempuh waktu dan jarak yang jauh bahkan memerlukan waktu beberapa jam, sehingga sistem ini akan sangat menyulitkan bagi mereka.

3. Biaya Yang Harus Dikeluarkan. Sistem ini pastinya memerlukan fasilitas dan tenaga pengajar yang lebih, maka tentunya diperlukan biaya untuk memenuhinya.

4. Kurangnya Tenaga Pengajar atau Guru. Seperti diketahui pembagian jatah guru yang timpang menjadi permasalahan berikutnya, banyak sekali sekolah yang tenaga pengajarnya sangat kurang, maka sistem ini juga akan tidak bisa dijalankan.

5. Kurangnya Fasilitas Sekolah. Jangankan untuk menjalankan kegiatan tambahan seperti olahraga dan seni, untuk bangunan kelas saja sekolah masih sering menghadapi permasalahan. Maka sistem ini 
dipastikan tidak akan berjalan dengan baik dan tidak sesuai dengan tujuan.

6. Timbulnya Rasa Bosan Di Sekolah. Kegiatan yang monoton karena permasalahan di atas pada waktunya akan menimbulkan rasa bosan bagi anak bahkan tenaga pendidik yang akan menjalankan sistem ini dengan banyak sekali permasalahan yang ada.

\section{Pengertian Prestasi Belajar}

Belajar ialah suatu proses usaha yang dilakukan seseorang untuk memperoleh suatu perubahan tingkah laku yang baru secara keseluruhan, sebagai hasil pengalamannya sendiri dalam interaksi dengan lingkungannya. ${ }^{18}$ Perubahan itu tidak hanya berkaitan dengan penambahan ilmu pengetahuan tetapi juga berbentuk kecakapan, keterampilan, sikap, perilaku, harga diri, minat, watak, dan penyesuaian diri.

Maslow menyebutkan: Bahwa belajar itu berpusat pada kehendak, kesadaran dan aktifitas siswa serta minat yang cukup darinya. Jadi menurut teori tersebut belajar tidak lepas dari timbulnya situasi dari dalam diri siswa, keinginan dan hasrat dari dalam merupakan pokok terjadinya apa yang dinamakan belajar yang membawa keberhasilan. Masalah minat dan keberhasilan siswa merupakan syarat mutlak bagi terjadinya proses belajar mengajar. ${ }^{19}$ Belajar bukanlah sekadar mengumpulkan pengetahuan. Belajar adalah proses mental yang terjadi dalam diri seseorang, sehingga menyebabkan munculnya perubahan perilaku. Aktifitas mental itu terjadi karena adanya interaksi individu dengan

\footnotetext{
${ }^{18}$ Slameto, Belajar \& Faktor faktor yang Mempengaruhi, (Jakarta: Rineka Cipta, 2010), h. 2.

${ }^{19}$ Muhaimin dkk, Strategi Belajar Dan Mengajar, (Surabaya: CV. Catur Media Karya Anak Bangsa, 1996 ), h. 23.
}

lingkungan yang disadari. ${ }^{20}$ Morgan dalam buku Intruction to Psychology mengemukakan belajar adalah setiap perubahan yang relatif menetap dalam tingkah laku yang terjadi sebagai suatu hasil dari latihan atau pengalaman. Witherington dalam buku Education Psichology mengemukakan belajar adalah suatu perubahan di dalam kepribadian yang menyatakan diri sebagai suatu pola baru daripada reaksi yang berupa kecakapan, sikap, kebiasaan, kepandaian, atau suatu pengertian. ${ }^{21}$

Menurut M. Sobry Sutikno dalam bukunya Menuju Pendidikan Bermutu, mengartikan belajar adalah suatu proses usaha yang dilakukan oleh seseorang untuk memperoleh suatu perubahan yang baru sebagai hasil pengalamannya sendiri dalam interaksi dengan lingkungannya. ${ }^{22}$ Thursan Hakim mengartikan belajar adalah suatu proses perubahan dalam segi kepribadian manusia dan perubahan tersebut terlihat dalam bentuk peningkatan kualitas dan kuantitas tingkah laku seperti peningkatan kecakapan, pengetahuan, sikap, kebiasaan, pemahaman, keterampilan daya fikir dan lain-lain kemampuannya menjadi lebih baik dari sebelumnya. ${ }^{23}$ Hal ini berarti peningkatan kualitas dan kuantitas tingkah laku seseorang diperlihatkan dalam bentuk bertambahnya kualitas dan kuantitas kemampuan seseorang dalam berbagai bidang. Apabila tidak terdapat perubahan dalam peningkatan kualitas dan kuantitas kemampuan, maka orang tersebut belum mengalami proses belajar atau dengan

${ }^{20}$ Wina Sanjaya, Strategi Pembelajaran

Berorientasi Standar Proses Pendidikan, h. 112

${ }^{21}$ Ngalim Purwanto, Psikologi

Pendidikan, (Bandung: PT Remaja Rosdakarya, 2011), h. 84

${ }^{22}$ Pupuh Fathurrohman dan M Sobri

Sutikno, Strategi Belajar Mengajar, (Bandung: PT Refika Aditama, 2014), h. 3.

${ }^{23}$ Ibid., h. 6. 
kata lain, ia mengalami kegagalan di dalam proses belajar. ${ }^{24}$

Dari beberapa definisi tersebut, dapat disimpulkan bahwa belajar pada hakikatnya adalah perubahan yang terjadi dalam diri seseorang menjadi pribadi yang lebih baik setelah melakukan aktivitas tertentu. Jadi antara prestasi dan belajar jika dikaitkan, maka dapat diambil pengertian bahwa prestasi belajar siswa adalah suatu hasil belajar siswa baik dalam bentuk pengetahuan, sikap dan ketrampilan.Prestasi belajar adalah sebuah kalimat yang terdiri dari dua kata, yakni "prestasi" dan "belajar" antara kata prestasi dan belajar mempunyai arti yang berbeda. Menurut W. J. S. Poerwadarminta prestasi adalah suatu hasil yang telah dicapai (dilakukan, dikerjakan, dan sebagainya). Dan prestasi dapat disimpulkan yaitu hasil yang telah dikerjakan dengan jalan keuletan kerja, baik secara invidual maupun kelompok dalam bidang tertentu. ${ }^{25}$ Muhibbin Syah berpendapat bahwa prestasi belajar diartikan sebagai tingkat keberhasilan siswa mencapai tujuan yang telah ditetapkan dalam sebuah program. ${ }^{26}$ Prestasi belajar adalah hasil yang dicapai oleh siswa selama proses belajar mengajar dalam kurun waktu tertentu. Hasil pengukuran dari belajar tersebut diwujudkan dalam bentuk angka, huruf, simbol, maupun kalimat yang menyatakan keberhasilan siswa selama proses pembelajaran. ${ }^{27}$

Prestasi belajar siswa biasanya dilanjutkan dengan nilai tes/angka nilai

\footnotetext{
${ }^{24}$ Hamdani, Strategi Belajar Mengajar, (Bandung: Pustaka Setia), h. 21.

${ }^{25}$ Slameto, Belajar \& Faktor faktor yang Mempengaruhi, h. 2.

${ }^{26}$ Muhibbin Syah, Psikologi Pendidikan dengan Pendekatan Baru, h. 139.

${ }^{27}$ Moh Zaiful Rosyid, Mustajab, dan Aminol Rosid Abdullah, Prestasi Belajar, (Malang: Literasi Nusantara, 2019), h. 9.
}

yang diberikan guru, sedangkan nilai tersebut diperoleh dengan mengadakan evaluasi sebelumnya dan akhirnya di dokumentasikan pada sebuah buku yang disebut rapot. Prestasi belajar menjadi titik akhir dalam menentukan keberhasilan pendidikan dalam mendidik siswanya dengan kegiatan-kegiatan terencana dan terstandarisasi.

\section{Tujuan Belajar}

Setiap manusia di mana saja berada tentu melakukan kegiatan belajar. Seorang siswa yang ingin mencapai cita-citanya tentu harus belajar dengan rajin. Bukan hanya di sekolah saja, tetapi juga harus belajar di rumah, masyarakat, lembagalembaga pendidikan ekstra di luar sekolah, berupa kursus, les privat, bimbingan studi, dan sebagainya. Untuk dapat mencapai cita-cita tidak bisa dengan bermalas-malas, tetapi harus rajin, gigih dan tekun belajar. Belajar adalah syarat mutlak untuk pandai dalam segala hal, baik dalam bidang ilmu pengetahuan maupun keterampilan atau kecakapan.

Dari uraian diatas jelaslah bahwa belajar merupakan kegiatan penting yang harus dilakukan setiap orang secara maksimal untuk dapat menguasai atau memperoleh sesuatu. Karena itu perlu diketahui seluk-beluk belajar, terutama bagaimana caranya. Belajar bertujuan mengadakan perubahan didalam diri antara lain tingkah laku. Belajar bertujuan mengubah kebiasaan dari yang buruk menjadi lebih baik, mengubah sikap, dari negatif menjadi positif, tidak hormat menjadi hormat, dan sebagainya. Dengan belajar dapat mengubah keterampilan. Belajar bertujuan menambah pengetahuan dalam berbagai bidang ilmu. ${ }^{28}$ Jadi, belajar bertujuan untuk mengubah manusia menjadi lebih baik.

\footnotetext{
${ }^{28} \mathrm{M}$ Dalyono, Psikologi Pendidikan,
} (Jakarat: PT Rineka Cipta 2005), h. 41-50. 
2. Faktor-Faktor Yang Mempengaruhi Hasil Belajar

Kegiatan belajar dilakukan oleh setiap siswa, karena melalui belajar mereka memperoleh pengalaman dari situasi yang dihadapinya. Dengan demikian belajar berhubungan dengan perubahan dalam diri individu sebagai hasil pengalamannya di lingkungan. Namun dalam prosesnya ada beberapa faktor yang mempengaruhi prestasi belajar siswa. Prestasi belajar siswa amat terkait dengan kualitas pembelajaran yang dicapai oleh siswa. Hal ini sebagaimana pernyataan: "faktor kunci yang sangat tekait dengan prestasi berupa kualitas pembelajaran. Semakin banyak jumlah cakupan isi, maka semakin tinggi skor prestasi”. Faktor-faktor yang mempengaruhi hasil belajar ataupun belajar pada dasarnya dapat dikategorikan ke dalam dua faktor, yaitu faktor yang berasal dari dalam diri pelajar dan faktor yang datang dari luar diri pelajar atau faktor lingkungan. Faktor-faktor yang mempengaruhi belajar digolongkan menjadi dua bagian:

1) Faktor internal (faktor yang yang berasal dalam diri)

a) Aspek Psikologi

1) Intelegensi. Intelegensi pada umumnya dapat diartikan sebagai kemampuan psiko-fisik untuk mereaksi rangsangan atau menyesuaikan diri dengan lingkungan dengan cara yang tepat. Jadi, intelegensi sebenarnya bukan persoalan kualitas otak saja, melainkan juga kualitas organ-organ tubuh yang lainnya. Akan tetapi, memang harus diakui bahwa peran otak dalam hubungannya dengan intelegensi manusia lebih menonjol dari pada peran organ-organ tubuh lainnya, lantaran otak merupakan "pusat" hampir seluruh aktifitas manusia. Tingkat kecerdasan atau intelegensi (IQ) sangat menentukan tingkat keberhasilan belajar siswa. Ini bermakna, semakin tinggi kemampuan intelegensi seorang siswa, maka semakin besar peluangnya untuk meraih sukses. Sebaliknya, semakin rendah kemampuan intelegensi seorang siswa maka semakin kecil peluangnya untuk memperoleh sukses. ${ }^{29}$

2) Sikap siswa. Sikap siswa adalah gejala internal yang berdimensi berupa kecenderungan untuk mereaksi atau merespon dengan cara yang relative tetap terhadap objek orang, barang dan sebagainya. Sikap dan penampilan siswa didalam kelas juga merupakan aspek lain yang bisa mempengaruhi proses pembelajaran. Adakalanya di temukan siswa yang sangat aktif dan adapula siswa yang pendiam, tidak sedikit juga ditemukan siswa yang memiliki motivasi yang rendah dalam belajar. semua itu akan mempengaruhi proses pembelajaran di dalam kelas. ${ }^{30}$

3) Bakat siswa. Secara umum bakat adalah kemampuan yang dimiliki seseorang untuk mencapai keberhasilan pada masa yang akan datang. Jadi bakat dapat diartikan sebagai, kemampuan individu untuk melakukan tugas tertentu tanpa banyak bergantung pada upaya pendidikan dan pelatihan. Bakat dapat mempengaruhi tinggi rendahnya prestasi belajar siswa pada bidang-bidang tertentu. Pemaksaan kehendak seorang siswa dan juga ketidaksadaran siswa terhadap bakatnya sendiri sehingga ia memilih ekstrakurikuler tertentu yang sebenarnya bukan menjadi bakatnya, hal itu akan berpengaruh buruk terhadap kinerja akademik (academic

\footnotetext{
${ }^{29}$ Muhibbin Syah, Psikologi Pendidikan dengan Pendekatan Baru, h. 131.

${ }^{30}$ Wina Sanjaya, Strategi Pembelajaran Berorientasi Standar Proses Pendidikan, h. 54.
} 
performance) atau prestasi belajarnya. $^{31}$

4) Motivasi siswa. Motivasi adalah perubahan energi dalam diri seseorang yang ditandai dengan munculnya feeling dan didahului dengan tanggapan terhadap adanya tujuan. ${ }^{32}$ Motivasi sangat mempengaruhi proses belajar siswa, karena seseorang yang tidak mempunyai motivasi dalam belajar tidak akan mungkin melakukan aktivitas belajar. Seseorang yang tidak belajar, bagaimana mungkin bisa berprestasi dalam belajar. Motivasi juga menjadi sistem reward yang baik untuk mencapai prestasi belajar. ${ }^{33}$ Dengan dorongan yang ditimbulkan oleh motivasi belajar, secara tidak langsung siswa akan terus berusaha untuk mencapai hasil yang maksimal dalam belajar.

5) Minat siswa. Secara sederhana minat berarti kecenderungan dan kegairahan yang tinggi atau keinginan yang besar terhadap sesuatu. ${ }^{34}$ Apabila siswa memiliki kegairahan yang tinggi dalam belajar, maka ia akan terus berusaha dan giat belajar untuk mencapai hasil belajar yang baik.

b) Aspek Fisiologis. Kondisi umum jasmani yang menandai kebugaran organ-organ tubuh dan sendi-sendinya dapat mempengaruhi semangat dan intensitas siswa dalam mengikuti pelajaran. Kondisi organ tubuh yang lemah, apalagi jika disertai sakit, hal

\footnotetext{
${ }^{31}$ Muhibbin Syah, Psikologi Pendidikan dengan Pendekatan Baru, h. 133.

${ }^{32}$ Sardian A. M, Interaksi dan Motivasi Belajar Mengajar, (Jakarta: Rajawali Pers, 2012), h. 73 .

${ }^{33}$ Moh. Zaiful Rosyid dan Aminol Rosid abdullah, Reward dan Punishment Dalam Pendidikan, (Malang: Literasi Nusantara, 2018), h. 45.

${ }^{34}$ Muhibbin Syah, Psikologi Pendidikan dengan Pendekatan Baru, h. 133
}

tersebut akan mempengaruhi konsentrasi belajar siswa. ${ }^{35}$ Apabila siswa sehat, maka siswa dapat belajar dengan penuh konsentrasi.

2) Faktor Eksternal (yang berasal dari luar diri)

Ki Hajar Dewantara mengemukakan teori tri pusat pendidikan dengan menyatakan: "Didalam hidupnya anak-anak ada tiga tempat pergaulan yang menjadi pusat pendidikan yang amat penting baginya yaitu alam keluarga, alam perguruan (sekolah) dan alam pergerakan pemuda (masyarakat)". ${ }^{36}$ Jadi ada 3 faktor yang berasal dari luar diri yaitu:

a) Faktor lingkungan keluarga. Faktor lingkungan rumah atau keluarga ini merupakan lingkungan pertama dan utama pula dalam menentukan keberhasilan belajar seseorang. Suasana lingkungan rumah yang cukup tenang, adanya perhatian orang tua terhadap perkembangan proses belajar dan pendidikan anak-anaknya maka akan mempengaruhi keberhasilan belajar. Purwanto menyebutkan bahwa yang termasuk faktor sosial adalah: "keluarga atau keadaan rumah tangga, kalau anak berada dalam sebuah keluarga yang harmonis, maka anak akan betah tinggal dalam keluarga tersebut dan kegiatan belajarnya akan terarah". Dengan keadaan yang demikian maka prestasi belajar anak akan meningkat. Begitu juga sebaliknya, jika anak hidup dalam keluarga yang kurang harmonis, penuh dengan percekcokan, maka anak menjadi tidak betah tinggal dalam keluarga. Keadaan demikian akan membuat anak malas belajar sehingga

\footnotetext{
${ }^{35}$ Ibid., h. 130-135.

${ }^{36}$ Pustaka aslikan, "Tri Pusat Pendidikan" artikel diak-ses pada 09 Oktober 2019 dari https://pustaka aslikan.blogspot.com/2011/11/tripusatpendidikan.html?m=1
} 
prestasi belajarnya menurun. Jadi, lingkungan keluarga sangat berpengaruh terhadap prestasi belajar anak dari sifat-sifat orang tua, praktik pengelolaan keluarga, ketegangan keluarga, dan demografi keluarga, semuanya dapat memberi dampak baik atau buruk terhadap kegiatan belajar dan hasil yang dicapai oleh siswa. ${ }^{37}$

b) Faktor lingkungan sekolah. Lingkungan sekolah sangat diperlukan untuk menentukan keberhasilan belajar siswa di sekolah mencakup metode mengajar, kurikulum, relasi guru dengan siswa, relasi siswa dengan siswa, pelajaran, waktu di sekolah, tata tertib atau disiplin yang ditegakkan secara konsekuen dan konsisten, keadaan gedung, dan metode belajar. Dengan begitu pihak sekolah harus memperhatikan segala kebutuhan siswanya, agar siswa betah berlamalama belajar di sekolah.

c) Faktor lingkungan masyarakat. Seorang siswa hendaknya dapat memilih lingkungan yang dapat menunjang keberhasilan belajar. Masyarakat merupakan faktor intern yang juga berpengaruh terhadap belajar siswa karena keberadaannya dalam masyarakat. Kondisi masyarakat di lingkungan kumuh yang serba kekurangan $^{38}$ dan suasana yang ramai akan mempengaruhi konsentrasi belajar siswa. Lingkungan yang dapat menunjang keberhasilan belajar diantaranya adalah: lembaga-lembaga pendidikan non formal seperti: kursus bahasa asing, bimbingan tes, pengajian remaja dan lain-lain

3. Cara Mengukur Prestasi Belajar

Keberhasilan program pembelajaran dapat diketahui dari

\footnotetext{
${ }^{37}$ Muhibbin Syah, Psikologi Pendidikan dengan Pendekatan Baru, h. 135.

${ }^{38}$ Ibid., h. 135.
}

kemampuan yang telah dimiliki siswa. Untuk mengetahui kemampuan yang dicapai siswa perlu dilakukan penilaian. Penilaian yang dilakukan guru mencakup semua hasil belajar siswa, yaitu kemampuan kognitif, afektif, dan psikomotor. Hasil belajar siswa digunakan untuk memotivasi siswa dan guru agar melakukan perbaikan dan peningkatan kualitas proses pembelajaran. Ada dua teknik evaluasi yaitu tes dan non tes. Adapun kedua teknik tersebut yaitu: ${ }^{39}$

a.Teknik Tes. Setiap orang yang melakukan proses belajar akan mengalami suatu perubahan dalam dirinya. Perubahan yang ada pada diri siswa baik berupa pengetahuan, keterampilan maupun sikap yang menunjukkan bahwa anak tersebut telah mempunyai prestasi belajar. Perubahan tersebut dapat dilihat secara langsung atau tidak. Perubahan yang tidak dapat dilihat secara langsung dapat diketahui dengan cara pemberian tes. Tes merupakan alat pengukuran berupa pertanyaan, perintah dan petunjuk yang ditujukan kepada testee untuk mendapatkan respon sesuai dengan petunjuk itu. Jadi tes yang digunakan dalam ujian adalah untuk mengetahui sejauh mana tingkat keberhasilan belajar siswa terhadap proses belajar yang telah dilakukannya pada bidang studi tertentu. Pada umumnya tes digunakan untuk mengadakan penilaian terhadap intelegensi, kemampuan dan kecakapan berfikir siswa. Dengan demikian dapat disimpulkan bahwa tes merupakan suatu alat ukur atau evaluasi tingkat prestasi belajar siswa di sekolah. Untuk mengukur dan mengevaluasi tingkat keberhasilan belajar tersebut, maka dilakukan tes sebagai berikut:

1) Tes Penempatan. Tes jenis ini disajikan pada awal tahun pelajaran untuk mengukur kesiapan siswa dan mengetahui tingkat pengetahuan yang

${ }^{39}$ Pupuh Fathurrohman dan M Sobri Sutikno, Strategi Belajar Mengajar, h. 77. 
telah dicapai sehubungan dengan pelajaran yang akan disajikan. Dengan demikian siswa dapat ditempatkan pada kelompok yang sesuai dengan tingkat pengetahuan yang dimiliki.

2) Tes Formatif. Penilaian ini digunakan untuk mengukur setiap satuan bahasan tertentu dan bertujuan hanya untuk memperoleh gambaran tentang daya serap siswa terhadap satuan bahasan tersebut. Hasil tes ini digunakan untuk memperbaiki proses belajar mengajar bahan tertentu dalam waktu tertentu atau sebagai umpan balik dalam memperbaiki proses belajar mengajar. Siswa dapat mengetahui bagian bahan pelajaran mana yang masih belum dikuasainya agar dapat mengupayakan perbaikannya. Pendidik juga dapat melihat bagian mana yang umumnya belum dikuasai siswa, sehingga dapat mengupayakan penjelasan yang lebih baik dan luas agar mereka dapat menguasai pelajaran tersebut.

3) Tes Diagnostik. Tes ini bertujuan mendiagnosis kesulitan belajar siswa untu mengupayakan perbaikannya. Karena tujuannya untuk mendiagnosis kesulitan belajar siswa, pendidik harus terlebih dahulu mengetahui bagian mana dari pendidikan yang memberikan kesulitan belajar pada siswa.

4) Tes Sumatif. Penilaian ini biasanya dilakukan pada akhir tahun ajaran untuk mengukur daya serap siswa terhadap pokok-pokok bahasan yang telah disampaikan oleh guru selama satu periode. Tujuannya adalah untuk menetapkan tingkat keberhasilan belajar siswa dalam suatu periode belajar tertentu. Adapun hasil dari test ini digunakan untuk menentukan kenaikan kelas, menyusun peringkat siswa.

b. Teknik non Tes. Teknik non tes pada umumnya digunakan untuk menilai sejauh mana kemampuan siswa yang berkaitan dengan kepribadian, perubahan sikap dan tingkah laku serta akhlak siswa ketika berinteraksi dengan guru dan teman-temannya dalam proses kegiatan belajar mengajar di sekolah. Hal-hal yang termasuk non tes seperti observasi, wawancara, skala sikap, angket, check list dan ranting scale.

\section{Metodologi Penelitian}

Jenis penelitian ini adalah penelitian kualitatif deskriptif, yaitu data yang dikumpulkan berbentuk kata-kata, gambar, bukan angka-angka. ${ }^{40}$ Menurut Bogdan dan Taylor, sebagaimana yang dikutip oleh Lexy J. Moleong, penelitian kualitatif adalah prosedur penelitian yang menghasilkan data deskriptif berupa katakata tertulis atau lisan dari orang-orang dan perilaku yang diamati. ${ }^{4}$

Sementara itu, penelitian deskriptif adalah suatu bentuk penelitian yang ditujukan untuk mendeskripsikan atau menggambarkan fenomena-fenomena yang ada, baik fenomena alamiah maupun rekayasa manusia. ${ }^{42}$ Adapun tujuan dari penelitian deskriptif adalah untuk membuat pencandraan secara sistematis, faktual, dan akurat mengenai fakta dan sifat populasi atau daerah tertentu. Penelitian ini digunakan untuk mengetahui bagaimana penerapan sistem full day school Dalam Meningkatkan Prestasi Belajar Siswa Kelas VIII di MTs Al Husna Kota Tangerang".Pendekatan dalam Penelitian ini menggunakan analisis diskriptif kualitatif. Adapun teknik pengumpulan data, selain studi pustaka, observasi,

${ }^{40}$ Sudarwan Danim, Menjadi Peneliti Kualitatif Rancangan Metodologi, Presentasi, dan Publikasi Hasil Penelitian untuk Mahasiswa dan Penelitian Pemula Bidang Ilmu Sosial, Pendidikan, dan Humaniora, (Bandung: Remaja Rosdakarya, 2002), Cet. I, h. 51

${ }^{41}$ Lexy. J. Moleong, Metodologi Penelitian Kualitatif Edisi Revisi, (Bandung: PT Remaja Rosdakarya, 2017), h. 3

${ }^{42}$ Lexy. J. Moleong, Metodologi Penelitian Kualitatif, h. 17 
diskusi, dan juga menggunakan analisis data melalui penelaahan yang dilakukan secara intensif, mendetail, dan komprehensif, yaitu dilakukan pencocokan atau kesesuaian perkembangan pendidikan di Indonesia.

\section{Hasil Penelitian Dan Pembahasan}

A. Temuan Penelitian Umum

1. Sejarah MTs Al-Husna Kota Tangerang

Mts. Al-Husna adalah sekolah yang dikelola dari sebuah yayasan yang bernama yayasan Al-Husna yang bertempatkan di Jln. A. Damyati No. 43 - 45 Kel. Sukarasa Kec. Tangerang. Keberadaan Madrasah Tsanawiyah pada sekitar tahun delapan puluhan, boleh dikatakan nyaris hilang bahkan sempat vakum beberapa tahun, baru tahun 1989, atas inisiatif bapak H. Moh. Sobri llyas Madrasah Tsanawiyah dimunculkan kembali. Alhamdulillah berkat perjuangan dan kerja keras Madrasah Tsanawiyah muncul kembali, diawal perjalanan MTs hanya mempunyai murid 8 orang, dan tahun ketiga MTs Al-Husna mengalami masa kejayaan dan Drs. Syarif Waddi adalah kepala madrasah pertama dan sekarang dipimpin oleh Hasan Basri, S.Hi.

Sebagaimana dimaklumi Madrasah Tsanawiyah sudah ada di lokasi Jl. A. Damyati No. 43-45 Kota Tangerang yang dipimpin oleh H. M. Thob'ami, Lc, yang pada umumnya mereka belajar di Madrasah Tsanawiyah ini sambil pesantren. Lokasi pesantren berada dalam komplek Al-Husna. Sekitar tahun 1985an Madrasah Tsanawiyah ini pindah ke Panunggangan, sehingga terjadi kekosongan selama kurang lebih 3 tahun. Barulah pada tahun 1989 MTs Al-Husna dibuka kembali dengan tekad dan niat yang tulus dan ikhlas walaupun dengan siswa yang berjumlah 8 orang.

Perjalanan ini tidak selamanya mulus, sekitar tahun 1998 MTs mulai mengalami penurunan kuantitas siswa, hal ini disebabkan animo masyarakat yang semakin menurun terhadap bentuk sekolah madrasah. Tentunya hal ini merupakan tantangan tersendiri bagi Yayasan Pendidikan Al-Husna dalam menciptakan image sekolah agama yang sejak awal merupakan cita-cita awal merupakan cita-cita awal khittah para pendiri. Namun dalam rangka mengemban misi agama, MTs terus berjalan dan nampak eksistensi dalam segala hal, diantaranya dengan menambah kegiatan dan sarana baik sarana kesenian maupun olahraga dan seni, disamping itu dalam rangka peningkatan sumber daya manusia MTs juga berusaha menempatkan guru yang berpengalaman pada bidangnya.

B. Temuan Penelitian Khusus

1. Implementasi Full Day School Dalam Meningkatkan Prestasi Belajar Siswa Kelas VIII di MTs Al-Husna

Full day school adalah sekolah dari pagi sampai sore, sehingga bisa mendapatkan banyak ilmu. Implementasi full day school di MTs Al-Husna sudah berlangsung sekitar dua tahun yang lalu. Alasan diterapkannya full day school di MTs Al-Husna, Pertama karena pada saat ini, terbatasnya waktu para orang tua siswa karena tuntutan pekerjaan dan sejumlah aktifitas lainnya, menjadikan intensitas berinteraksi dengan anak menjadi kurang. Sehingga orang tua tidak memiliki banyak waktu untuk mengawasi anaknya. Ditambah lagi dengan pergaulan anak yang semakin bebas, yang membutuhkan pengawasan lebih. Oleh karena itu, dengan diadakannya sistem full day school, aktifitas siswa di sekolah dapat terpantau oleh para guru. Dan waktu belajar siswapun menjadi lebih lama, dari pada waktu bermain.

Kedua, alasan diterapkannya full day school di MTs Al-Husna karena menyesuaikan dengan kondisi masyarakat disekitar sekolah dan mencoba untuk memenuhi kebutuhan masyarakat. contohnya seperti pangsa pasar. Pangsa pasar di kota Tangerang yaitu bandara internasional soekarno hatta. Karena MTs Al-Husna berdekatan dengan bandara internasional, maka siswa harus 
dipersiapkan. Sekalipun siswa taat beribadah, sesuai syariat Islam, siswa juga paham teknologi, mengerti bahasa asing, bahasa Inggris, bahasa Arab dan bahasa Mandarin. Maka dari itu, di MTs Al-Husna pembelajaran bahasa Inggris tidak hanya grammar tapi siswa juga belajar conversation, yang kedua yaitu bahasa Arab, karena bahasa Arab itu bahasa internasional, yang Ketiga yaitu bahasa Mandarin itu bahasa pangsa pasar, karena saat ini sudah banyak perusahaanperusahaan Cina, Korea. Waktu dalam sistem pembelajaran full day school di MTs Al-Husna diformat dari pukul 07.0014.30 WIB. Dimana waktu implementasi full day school di MTs Al-Husna untuk hari senin dimulai pada pukul 06.50 WIB sampai 07.30 WIB seluruh siswa dan para guru mengikuti upacara. Kemudian pukul 07.30 WIB sampai 08.40 WIB kegiatan belajar mengajar. Pukul 08.40 WIB sampai 09.20 WIBpembiasaan (me laksanakan ibadah sholat sunnah dhuha dan tadarus alqur'an). Pukul 09.20 WIB sampai 09.35 WIB istirahat (biasanya di waktu istirahat, para siswa jajan di kantin dan berbincangbincang dengan teman). Pukul 09.35 WIB sampai 11.50 WIB kegiatan belajar mengajar. Pukul 11.50 WIB sampai 12.40 WIB melaksanakan ibadah sholat dzuhur secara berjama'ah dan makan siang. Pukul 12.40 WIB sampai 13.50 WIB kegiatan belajar mengajar. Pukul 13.50 WIB sampai 15.00 WIB takhfidzul qur'an. Pukul 15.00 WIB sampai 15.30 WIB melaksanakan ibadah sholat ashar secara berjama'ah. Pukul 15.30 WIB sampai 16.30 WIB ekstrakurikuler bahasa Korea dan tilawah al-qur'an. Waktu implementasi full day school untuk hari selasa sampai kamis dimulai pada pukul 07.00 WIB sampai 08.45 WIB kegiatan belajar mengajar. Pukul 08.45 WIB sampai 09.20 WIB pembiasaan (melaksanakan ibadah sholat sunnah dhuha dan tadarus al-qur'an). Pukul 09.20 WIB sampai 09.55 WIB istirahat (biasanya di waktu istirahat, para siswa jajan di kantin dan berbincangbincang dengan teman). Pukul 09.55 WIB sampai 11.50 WIB kegiatan belajar mengajar. Pukul 11.50 WIB sampai 12.40 WIB melaksanakan ibadah sholat dzuhur secara berjama'ah dan makan siang. Pukul 12.40 WIB sampai 13.50 WIB kegiatan belajar mengajar. Pukul 13.50 WIB sampai 15.00 WIB, hari selasa dan kamis, takhfidzul qur'an, hari rabu PRAMUKA atau PASKIBRA. Pukul 15.00 WIB sampai 15.30 WIB melaksanakan ibadah sholat ashar secara berjama'ah. Pukul 15.30 WIB sampai 16.30 WIB ekstrakurikuler. Waktu implementasi full day school untuk hari jum'at, dimulai pada pukul 07.00 WIB sampai 08.15 WIB pembacaan surat Yasin bersama seluruh unit. Pukul 08.15 WIB sampai 09.25 WIB kegiatan belajar mengajar. Pukul 09.25 WIB sampai $10.00 \mathrm{WIB}$ istirahat (biasanya di waktu istirahat, para siswa jajan di kantin dan berbincang-bincang dengan teman). Pukul 10.00 WIB sampai 11.10 WIB kegiatan belajar mengajar. Pukul 11.10 WIB sampai 13.10 WIB melaksanakan ibadah sholat jum'at secara berjama'ah dan makan siang. Pukul 13.10 WIB sampai 14.55 WIB kegiatan belajar mengajar. Pukul 14.55 WIB sampai 15.30 WIB, melaksanakan ibadah sholat ashar secara berjama'ah. Pukul 15.30 WIB sampai 16.30 WIB ekstrakurikuler. Kegiatan belajar mengajar, tidak selalu di dalam mata pelajaran. Akan tetapi juga pada kegiatan-kegitan tambahan seperti pada apel pagi. Upaya penanaman nilainilai sopan santun dimulai sejak pagi. Para guru menyambut siswa yang baru datang tepat di depan gerbang. Program ini selain bertujuan untuk memberikan tauladan kepada siswa tentang kedisiplinan dan sopan santun, juga untuk membangun mood siswa agar antusias mengikuti kegiatan pembelajaran. 
Walaupun sekolahnya sudah modern, sudah berada di kota akan tetapi akhlakul karimahnya harus tetap melekat sehingga siswa bisa mewarnai kota Tangerang yang penuh dengan ragam budaya. Karena itu tidak cukup dengan hanya sekolah biasa, maka MTs Al-Husna juga menerapkan sistem tambahan yaitu sekolah semi pondok pesantren. Karena dengan sekolah semi pondok pesantren, siswa bisa mendapatkan lebih banyak ilmu agama, dari pada sekolah biasanya. Sehingga siswa bisa membawa orang tuanya ke dalam surga. Dan setelah lulus dari sini siswa juga diharapkan mampu memahami teknologi, dan memahami akidah islam dengan baik. Karena siswa di MTs Al-Husna setiap pagi dibiasakan untuk melaksanakan sholat dhuha, sehingga seimbang, orang tuanya bekerja, anaknya mendoakan orang tuanya. Sekolah semi pondok pesantren seperti program tahfidz al-Qur'an juz 29 dan juz 30, pembiasaan adzan, shalat dhuha, shalat dhuhur dan ashar berjama'ah, dzikir, membaca al-Qur'an sebelum mulai KBM, muhadhoroh 3 bahasa, muthola'ah, mahfudzot, khot dan imla. Selain sekolah semi pondok pesantren, ada juga program unggulan teknologi komputer seperti software, hardware, dan jaringan. MTs AlHusna menggunakan kurikulum 2013. Kurikulum 2013 dianggap sangat relevan dengan kebutuhan siswa. Karena kurikulum 2013 sesuai dengan visi MTs Al-Husna yaitu mencetak peserta didik yang berakhlakul karimah, berprestasi, dan mandiri. Guru menerapkan startegi pembelajaran yang berbeda seperti bermain, bernyanyi, praktek dan lain-lain. Strategi pembelajaran seperti itu diharapkan mampu mengubah suasana belajar lebih menyenangkan sehingga dapat meningkatkan motivasi belajar siswa.

Jumlah mata pelajaran yang diberikan kepada siswa sebanyak 14 Mata
Pelajaran dengan rincian 8 mata pelajaran umum, dan 6 mata pelajaran keagamaan. Selain pemberian mata pelajaran yang tertera diatas, di MTs Al-Husna juga terdapat kegiatan ekstrakurikuler yang dilaksanakan disela-sela KBM berlangsung. Kegiatan ekstrakurikulernya yaitu pramuka, taekwondo, marawis, english club, qiro'at, bahasa Korea, theater dan futsal.

2. Faktor Keunggulan dan Kelemahan Program Full Day School dalam Meningkatkan Prestasi Belajar Siswa Kelas VIII di MTs Al Husna Kota Tangerang. setiap adanya sebuah program, pasti disitu terdapat keunggulan dan kelemahan setelah program tersebut berjalan. Begitu juga dengan diterapkannya full day school di MTs Al-Husna. Faktor keunggulan implementasi full day school di MTs Al-Husna yaitu sebagai guru bisa memantau aktivitas siswa dari pagi sampai sore". Karena jaman sekarang semakin modern, pergaulan yang semakin bebas, sedangkan, terbatasnya waktu para orang tua siswa karena tuntutan pekerjaan dan sejumlah aktifitas lainnya, menjadikan intensitas berinteraksi dengan anak menjadi kurang. Sehingga orang tua tidak memiliki banyak waktu untuk mengawasi anaknya.

Faktor keunggulan lainnya yaitu siswa dapat menguasai pelajaran agama seperti tahfidz, akidah akhlak, dan tilawah. Sesuai dengan program unggulan MTs AlHusna yaitu tahfidz al-qur'an juz 29 dan juz 30. Kemudian faktor keunggulan lainnya yaitu pembentukan karakter. Faktor ini sesuai dengan visi MTs AlHusna yaitu mencetak peserta didik yang berakhlakul karimah. Faktor keunggulan lainnya yaitu, siswa bisa bersaing dengan sekolah-sekolah lainnya, sehingga ketika lulus dari MTs Al-Husna bisa masuk ke SMA Negeri favorit unggulan. Faktor keunggulan lainnya yaitu, optimalisasi pemanfaatan waktu. Dengan alokasi waktu yang sangat luas, waktu untuk menggali dan mengembangkan bakat siswa terbuka 
luas. Kegiatan sore hari bisa dimaksimalkan untuk melihat keahlian dan kecakapan siswa dalam semua bidang. Pada sore hari siswa bisa mengembangkan bakatnya melalui program ekstrakurikuler. Faktor keunggulan lainnya yaitu, Pembiasaan siswa dalam Beribadah. Khususnya bagi siswa yang beragama islam diwajibkan mengikuti program pembiasaan yaitu melaksanakan sholat dhuha, sholat dzuhur dan sholat ashar secara berjamaah, bahkan ditambah tadarus dan kegiatan keagamaan lainnya. Faktor kelemahan full day school di MTs AlHusna yaitu siswa membutuhkan uang jajan yang super lebih. Karena istirahatnya dua kali dan siswa membutuhkan asupan makanan, maka siswa akan manghabiskan uang jajan yang cukup banyak. Faktor kelemahan lainnya yaitu SDM pendidik dan tenaga pendidik. Siswa terkadang merasa lelah. Terutama siswa yang baru, karena belum terbiasa dari yang tadinya sekolah pulangnya dzuhur, sekarang di MTs dari pagi sampai sore. Hanya awalnya saja, seiring berjalannya waktu siswa mulai terbiasa dan bisa mengikuti program dengan baik. Kurangnya fasilitas sekolah seperti perpustakaan. Menjadi salah satu faktor kelemahan implementasi full day school di MTs Al-Husna. Timbulnya rasa bosan dan ngantuk di sekolah. Akan tetapi, para guru selalu memberikan pengajaran yang terbaik, agar siswanya tidak merasa bosan dan ngantuk.

3. Hasil implementasi full day school dalam meningkatkan prestasi belajar siswa kelas VIII di MTs Al-Husna. Bukti bahwa hasil dari sistem yang diterapkan di MTs AlHusna meningkatkan prestasi belajar siswa adalah nilai raport siswa, ada siswa yang ketika SD tidak mendapat ranking, ketika di MTs Al-Husna mendapatkan ranking, ada juga siswa yang ketika di SD ranking 10 besar, ketika di MTs Al-Husna ranking 3 besar. Ini menunjukkan dengan adanya sistem full day school prestasi belajar siswa menjadi meningkat. Bukti lain bahwa hasil dari sistem full day school yang diterapkan di MTs Al-Husna Kota Tangerang dalam meningkatkan prestasi belajar siswa yaitu dari keberhasilan para alumni lembaga ini masuk ke jenjang pendidikan yang lebih tinggi yang tergolong favorit di kawasan Tangerang dan sekitarnya.

Bukti keberhasilan kegiatan pembelajaran di MTs Al-Husna adalah perubahan yang menonjol terlihat pada siswa dalam hal sopan santun. Siswa menjadi disiplin dalam melaksanakan ibadah dirumah, hal ini karena pembiasaan ibadah disekolah seperti adzan, shalat dhuha, shalat dhuhur berjamaah, dzikir, membaca al-Qur'an yang diikuti oleh semua siswa. Terbatasnya waktu para orang tua siswa karena tuntutan pekerjaan dan sejumlah aktifitas lainya, menjadikan intensitas berinteraksi dengan anak menjadi kurang. Sehingga orang tua tidak memiliki banyak waktu mengajari putranya mengaji. Namun setelah bersekolah di MTs Al-Husna kemampuannya mengaji sungguh menggembirakan. Hal tersebut menunjukan konsep pendidikan yang dikembangkan di MTs Al-Husna Kota Tangerang terbukti efektif.

Sistem full day school yang diterapkan di MTs Al-Husna Kota Tangerang terbukti menjadikan peserta didik memiliki pengetahuan umum dan agama yang sama-sama baiknya. Hal itu terlihat dari sikap siswa yang memiliki akhlakul karimah.

C. Pembahasan Hasil Penelitian

1. Implementasi Full Day School Dalam Meningkatkan Prestasi Belajar Siswa Kelas VIII di MTs Al-Husna

Sistem pembelajaran di MTs AlHusna termasuk kategori full day school karena kegiatan belajar mengajar berlangsung dari pagi sampai sore hari. 
Implementasi full day school di MTs AlHusna sudah berjalan dengan baik, karena guru selalu berusaha dan berkreasi dalam menerapkan strategi pembelajaran yang bervariasi dengan menggunakan format permainan dalam proses belajar mengajar serta pembelajaran yang berbeda dengan biasanya. Karena penerapan kurikulum dengan struktur mata pelajaran yang lebih banyak, secara logis berakibat pada bertambahnya waktu belajar siswa dan beban mengajar guru. Hal ini akan membuat siswa menjadi lebih mudah bosan dan jenuh ketika mereka berada dalam sekolah yang cukup lama.

MTs Al-Husna mendesain suasana sekolah menjadi rumah kedua bagi siswa, dengan suasana belajar yang nyaman dapat memotivasi belajar siswa, sehingga siswa tidak akan merasa bosan untuk berlamalama belajar. Dengan implementasi full day school ini, maka MTs Al-Husna dapat mengarahkan dan membimbing siswanya untuk lebih menghargai waktu serta membiasakan diri untuk hidup dalam lingkungan yang agamis dan berperilaku akhlakul karimah dalam kehidupan bermasyarakat.

Dilaksanakan program full day school pada hakekatnya tidak hanya upaya menambah waktu, memperbanyak materi pelajaran, meningkatkan prestasi belajar, namun juga untuk mengkondisikan anak agar memiliki pembiasaan hidup yang baik, ini yang pertama. Kedua adalah memasukkan materi-materi keislaman kedalam bidang studi dan sebagai bidang studi tersendiri yang harus dikuasai oleh anak-anak sebagai bekal hidup. Ketiga untuk pembinaan kejiwaan, mental dan moral anak. Maksudnya adalah memberikan keseimbangan antara kebutuhan rohani dan jasmani agar terbentuk kepribadian yang utuh. Dengan MTs Al-Husna menerapkan sekolah semi pondok pesantren. Diharapkan setelah lulus dari MTs Al-Husna siswa menjadi terbiasa dalam beribadah, hafal Al-Qur'an juz 29 dan juz 30 dan mampu memahami teknologi komputer.

Dalam rangka memaksimalkan waktu luang anak-anak agar lebih berguna. Maka diterapkan sistem full day school dengan tujuan pembentukan akhlak dan akidah dalam menanamkan nilai-nilai yang positif, mengembalikan manusia pada fitrahnya sebagai khalifah di bumi dan sebagai hamba Allah serta memberikan dasar yang kuat dalam belajar disegala aspek. Dengan memberi tambahan waktu khusus untuk pendalaman pelajaran agama islam".10 Kegiatan tersebut juga masih sesuai dengan siswa MTs, yang masih membutuhkan pembiasaan yang baik dan contoh yang dapat dijadikan panutan sehingga dapat membentuk karakter nilainilai positif yang bisa meminimalisir dan menjadi filter dari pengaruh negatif di zaman globalisasi ini.

2. Faktor Keunggulan dan Kelemahan Program Full Day School dalam Meningkatkan Prestasi Belajar Siswa Kelas VIII di MTs Al Husna Kota Tangerang.

Faktor keunggulan implementasi full day school di MTs Al-Husna yaitu sebagai guru bisa memantau aktivitas siswa dari pagi sampai sore. ini salah satu keungglan yang tidak bisa dimiliki oleh sekolah lain yang hanya berlangsung selama setengah hari. Siswa dapat menguasai pelajaran agama seperti tahfidz, akidah akhlak, dan tilawah. Siswa diwajibkan mengikuti program pembiasaan yaitu melaksanakan sholat dhuha, sholat dzuhur dan sholat ashar secara berjamaah, bahkan ditambah tadarus dan kegiatan keagamaan lainnya. Sesuai dengan program unggulan MTs Al-Husna yaitu tahfidz al-qur'an juz 29 dan juz 30, dan sesuai dengan visi MTs Al-Husna yaitu membentukan karakter siswa.. Keunggulan seperti ini biasanya hanya terdapat di dalam sebuah pesantren. Namun dengan sistem baru, sekolah semi pondok 
pesantren, keunggulan tersebut ada di MTs Al-Husna. Faktor keunggulan lainnya yaitu, siswa bisa bersaing dengan sekolahsekolah lainnya, sehingga ketika lulus dari MTs Al-Husna bisa masuk ke SMA Negeri favorit unggulan. Optimalisasi pemanfaatan waktu. Dengan alokasi waktu yang sangat luas, waktu untuk menggali dan mengembangkan bakat siswa terbuka luas.

Faktor kelemahan full day school di MTs Al-Husna yaitu siswa membutuhkan uang jajan yang super lebih. Karena siswa berada di sekolah dengan waktu yang cukup lama, siswa juga membutuhkan asupan makanan, maka siswa akan manghabiskan uang jajan yang cukup banyak. Cara mengatasinya yaitu orang tua siswa membawakan bekal makanan, untuk dimakan ketika sedang istirahat. Siswa juga terkadang merasa lelah, bosan dan ngantuk di sekolah.. Terutama siswa yang baru, karena belum terbiasa. Cara mengatasi kelemahan ini, guru harus selalu memotivasi siswa, dan mengubah suasana kelas menjadi menyenangkan, dengan metode pengajaran yang bervariasi. Faktor kelemahan lainnya yaitu SDM pendidik dan tenaga pendidik. Upaya untuk mengatasi kelemahan tersebut yaitu para guru diwajibkan mengikuti pelatihan, untuk menambah wawasan supaya metode pengajarannya lebih bervariatif, dan harus lebih serimg melakukan diskusi juga antar teman sejawat. Supaya siswa tidak merasa bosan dan ngantuk.

3. Hasil implementasi full day school dalam meningkatkan prestasi belajar siswa kelas VIII di MTs Al-Husna

Bukti bahwa hasil dari sistem yang diterapkan di MTs Al-Husna meningkatkan prestasi belajar siswa adalah nilai raport siswa, ada siswa yang ketika SD tidak mendapat ranking, ketika di MTs Al-Husna mendapatkan ranking, ada juga siswa yang ketika di SD ranking 10 besar, ketika di MTs Al-Husna ranking 3 besar.
Ini menunjukkan dengan adanya sistem full day school prestasi belajar siswa menjadi meningkat. Bukti lain bahwa hasil dari sistem full day school yang diterapkan di MTs Al-Husna Kota Tangerang dalam meningkatkan prestasi belajar siswa yaitu dari keberhasilan para alumni lembaga ini masuk ke jenjang pendidikan yang lebih tinggi yang tergolong favorit di kawasan Tangerang dan sekitarnya. Bukti keberhasilan kegiatan pembelajaran di MTs Al-Husna adalah perubahan yang menonjol terlihat pada siswa dalam hal sopan santun. Siswa menjadi disiplin dalam melaksanakan ibadah dirumah, hal ini karena pembiasaan ibadah disekolah seperti adzan, shalat dhuha, shalat dhuhur berjamaah, dzikir, membaca al-Qur'an yang diikuti oleh semua siswa. Sistem full day school yang diterapkan di MTs AlHusna Kota Tangerang terbukti menjadikan peserta didik memiliki pengetahuan umum dan agama yang samasama baiknya. Hal itu terlihat dari sikap siswa yang memiliki akhlakul karimah.

\section{Kesimpulan}

Berdasarkan uraian yang telah peneliti kemukakan pada Pembahasan sebelumnya maka peneliti mengemukakan isi dari keseluruhan inti penelitian berupa kesimpulan yaitu sebagai berikut;

1. Implementasi Full day school dalam meningkatkan prestasi belajar siswa kelas VIII di MTs Al-Husna. Implementasi full day school di MTs Al-Husna sudah berjalan dengan baik, karena guru selalu berusaha dan berkreasi dalam menerapkan strategi pembelajaran yang bervariasi dengan menggunakan format permainan dalam proses belajar mengajar serta pembelajaran yang berbeda dengan biasanya. MTs Al-Husna juga menggunakan metode dan media yang tepat yang sesuai dengan mata pelajaran. Penataan bangku dan tempat duduk siswa. Dan juga formasi tempat duduk 
yang berubah agar siswa tidak merasa jenuh. Pembelajaran tidak hanya berpusat indoor (di dalam kelas) melainkan berpusat outdoor (diluar kelas) seperti pembelajaran dilaksanakan di masjid. MTs Al-Husna juga mengadakan program keagamaan yang diwajibkan kepada seluruh siswanya yaitu dengan menerapkan pembiasaan, adzan, shalat dhuha, shalat dzuhur, shalat ashar berjamaah, dzikir, serta membaca alQur'an

2. Faktor Keunggulan dan Kelemahan Program Full Day School dalam Meningkatkan Prestasi Belajar Siswa Kelas VIII di MTs Al Husna Kota Tangerang. Setiap adanya sebuah program, pasti disitu terdapat keunggulan dan kelemahan setelah program tersebut berjalan. Begitu juga dengan diterapkannya full day school di MTs AlHusna. Faktor keunggulannya yaitu sebagai guru bisa memantau aktivitas anak dari pagi sampai sore. siswa dapat menguasai pelajaran agama seperti tahfidz Al-Qur'an juz 29 dan juz 30, akidah akhlak, dan tilawah. Mencetak siswa yang berakhlakul karimah. Siswa bisa bersaing dengan sekolah-sekolah lainnya. Optimalisasi pemanfaatan waktu. Pembiasaan Anak dalam Beribadah. Faktor kelemahannya yaitu siswa membutuhkan uang jajan yang super lebih. Kurangnya SDM pendidik dan tenaga pendidik. Siswa terkadang merasa lelah. Terkadang siswa merasa bosan dan ngantuk di sekolah.

3. Hasil implementasi full day school dalam meningkatkan prestasi belajar siswa kelas VIII di MTs Al-Husna. Adapun hasil lain dari implementasi full day school dalam meningkatkan prestasi belajar siswa kelas VIII di MTs Al-Husna yaitu siswa mendapatkan nilai raport yang lebih baik setelah mengikuti full day school. Siswa terbiasa shalat dhuha, shalat dhuhur dan ashar berjama'ah, dzikir, membaca al-Qur'an, tanpa harus diperintah oleh orang tua. Siswa mampu membaca al-Qur'an sesuai dengan tajwid. Siswa mampu menghafal Al-Qur'an juz 29 dan juz 30. MTs Al-Husna juga mengadakan kegiatan ekstrakurikuler sebagai penunjang prestasi belajar siswa seperti rebana, tilawah dan pidato. Keberhasilan para alumni lembaga ini masuk ke jenjang pendidikan yang lebih tinggi yang tergolong favorit di kawasan Tangerang dan sekitarnya.

\section{DAFTAR PUSTAKA}

Abu Thaib, "Strategi Full Day School dalam Meningkatkan Prestasi Belajar Siswa Kelas IX A di MTs Al-Bukhary Labuan Sreseh Sampang" artikel diakses pada 07 Oktober 2019 dari http://etheses.uim-malang.ac.id

Alfi Sa'adah, "Implementasi Full Day School dalam Membentuk Kualitas Akhlak Siswa di SD Al-Gontory Tulung Agung." artikel diak-ses pada 07 Oktober 2019 dari http://repo.iain-tulungagung.ac.id

Baharuddin. Pendidikan dan Psikologi Perkembangan. Jogjakarta: ArRuzz Media. 2010.

Bogdan C. R. and Biklen S. K. Quantitative Research for Education: An Introduction to Theory and Methods. Terj. Munandir. (1990). Jakarta: Direktorat Jenderal Pendidikan Tinggi Departemen Pendidikan dan Kebudayaan.

Bogdan C. R. and Taylor. Introduction In Qualitative Research Methods. New York: John Wiley \& Son Inc. 1993. 
Chabib Thoha dkk. Metodologi Pengajaran Agama. Yogyakarta: Pustaka Pelajar. 1989.

Creswell, John W. Qualitative and Quantitative Approaches. LondonNew Delhi: Sage Publication. 1994

Creswell, John W. Qualitative Inquiry and Research Design: Choosing among Five Tradision. New Delhi: Sage Publication. 1998.

Creswell, John W. Educational Research. New Jersey: Pearson Education. Third Edition. 2008.

Dalyono, M. Psikologi Pendidikan. Jakarat: PT Rineka Cipta. 2005.

Departeman Pendidikan Dan Kebudayaan. Kamus Besar Bahasa Indonesia, Jakarta: Balai Pustaka. 1995.

Deddy Mulyana. Metodologi Penelitian Kualitatif, Bandung: PT Remaja Rosdakarya. 2004.

Fathurrohman, Pupuh dan M Sobri Sutikno. Strategi Belajar Mengajar. Bandung: PT Refika Aditama. 2014.

Hamdani. Strategi Belajar Mengajar Bandung: Pustaka Setia

Jamal Ma'mur Asmani. Full Day School Konsep Manajemen dan Quality Control. Yogyakarta: AR-RUZZ MEDIA. 2017.

Muhaimin dkk. Strategi Belajar Dan Mengajar. Surabaya: CV. Catur Media Karya Anak Bangsa. 1996.

Lexy J. Moleong. Metodologi Penelitian Kualitatif, Bandung: PT. Remaja Rosdakarya. 1998.

Masri Singarimbun. Metode Penelitian Survai, Jakarta : LP3ES. 1989.

M Sobri Sutikno dan Pupuh Fathurrohman. Strategi Belajar Mengajar. Bandung: PT Refika Aditama. 2014.

Noeng Muhadjir. Metode Penelitian Kualitatif, Yogyakarta: Rakesarasin. 1998.
Purwanto, Ngalim. Psikologi Pendidikan. Bandung: PT Remaja Rosdakarya. 2011.

Pustaka aslikan, "Tri Pusat Pendidikan" artikel diak-ses pada 09 Oktober 2019

darihttps://pustakaaslikan.blogspot. com/2011/11/tripusatpendidikan.ht $\mathrm{ml} ? \mathrm{~m}=1$

Rosyid, M. Z, Mustajab dan Aminol Rosid abdullah. Prestasi Belajar. Malang: Literasi Nusantara. 2019.

Sanjaya, Wina. Strategi Pembelajaran Berorientasi Standar Proses Pendidikan. Jakarta: Kencana Prenada Media. 2011.

Sardian A. M. Interaksi dan Motivasi Belajar Mengajar. Jakarta: Rajawali Pers. 2012.

Sedarmayanti dan Syarifudin Hidayat. Metodologi Penelitian Bandung: Mandar Maju. 2011.

Sudiyono, Anas. Pengantar Evaluasi Pendidikan. Jakarta: PT Raja Grafindo Persada. 2008.

Sugiono. Metode Penelitian Pendidikan. Bandung: Alfabeta. 2010.

Sugiyono. Metode Penelitian Tindakan Komprehensif. Bandung: Alfabeta. 2015.

Sugiyono. Memahami Penelitian Kualitatif, Bandung: Simbiosa. 2009.

Suharsimi Arikunto. Prosedur Penelitian, Yogyakarta: Rineka Cipta. 1990.

Suharsimi Arikunto. Prosedur Penelitian Suatu Pendekatan Praktek, Jakarta: PT. Rineka Cipta. 2002.

Sulistyaningsih, Wiwik. Full Day School dan Optimalisasi Perkembangan Anak. Yogyakarta: Paradigma Indonesia. 2008.

Supriadie, Didi dan Deni Darmawan. Komunikasi Pembelajaran. Bandung: PT Remaja Rosdakarya. 2012. 
Syaodih, S. N. Landasan Psikologi Pendidikan. Bandung:PT.Rema Rosdakarya. 2009

Slameto. Belajar \& Faktor faktor yang Mempengaruhi. Jakarta: Rineka Cipta. 2010.

Syah, Muhibbin. Psikologi Pendidikan. Bandung: PT Remaja Rosdakarya. 2010.

Tirtarahardja, Umar dan S. L. La Sulo. Pengantar Pendidikan. PT Rineka Cipta. 2005
Undang-undang Republik Indonesia No 20 tahun 2003. tentang Sisdiknas dan Peraturan Pemerintah Tahun 2010 tentang Penyelenggaraan Pendidikan serta Wajib Belajar. Bandung: Citra Umbara. 2011.

Yusuf, A Muri. Metode Penelitian Kuantitatif, Kualitatif, Dan Penelitian Gabungan. Jakarta: Prenadamedia Group. 2014. 
Implementasi Full Day School Dalam Meningkatkan Prestasi Belajar Siswa Kelas VIII Di MTs. Al-Husna Kota Tangerang Banten 